Thorax, 1980, 35, 745-750

\title{
Unilateral hyperlucent lung: the case for investigation
}

\author{
SHEILA A McKenZIE, D J ALliSON, M P SINGH, AND S GODFREY \\ From the Department of Paediatrics and Neonatal Medicine and Department of Diagnostic Radiology, \\ Hammersmith Hospital, London
}

ABSTRACT Seventeen children with unilateral hyperlucent lungs were referred for investigation. Of the 11 who had a referring diagnosis of possible Macleod's syndrome only two were shown to have post-viral bronchiolitis. Three of the 11 had conditions that required surgical treatment and a further two with bronchiectasis were treated medically. To avoid confusion we suggest that Macleod's syndrome is reserved exclusively for children with post-viral bronchiolitis. Radioisotopic regional lung function studies were useful in the investigation of the subjects from three points of view. Firstly, they distinguished children with primary perfusion abnormalties and normal ventilation, secondly, they defined the extent of altered respiratory function, and thirdly, they were able to distinguish compensatory emphysema from congenital lobar emphysema. As bronchography and bronchoscopy may be hazardous in small children with poor respiratory reserve, such regional studies may be useful in indicating which patients do not require further invasive investigation.

Of the many causes of unilateral hyperlucent lung in children, congenital lobar emphysema and foreign body inhalation are among the most common. In general neither of these conditions is difficult to diagnose and the affected lung, or lobe, is usually hyperinflated. There is, however, a small group of children with hyperlucent lungs in whom the diagnosis is not immediately apparent. Unilateral hyperlucent lungs which are normal or small in size are occasionally seen on radiographs in children who present with longstanding respiratory symptoms. Macleod's or Swyer-James syndrome $^{12}$ presents in this way and is now believed to follow respiratory infections such as measles, ${ }^{3}$ adenovirus, ${ }^{4}$ and mycoplasma. ${ }^{35}$ Bronchograms show poor filling of the peripheral bronchi and histologically the bronchi and bronchioles show evidence of chronic inflammatory changes. Some clinicians nevertheless prefer to use the term Macleod's syndrome simply to describe the radiographic appearances and do not imply any aetiology.

Over the past three years 17 children with unilateral hyperlucent lungs have been referred to us for investigation. In many of these children the

Address for reprint requests: Dr SA McKenzie, Department of Paediatrics and Neonatal Medicine, Hammersmith Hospital, Du Cane Road, London W12 0HS aetiological diagnosis was uncertain at the time of referral; 11 were referred with a possible diagnosis of Macleod's syndrome. We describe here the results of our investigations and suggest a line of investigation for children presenting in this way.

\section{Methods}

The age of patients, history, presenting symptoms and signs, chest radiograph appearances, and initial diagnoses are shown in table 1 . Seven children were known to have congenital heart disease but it was not clear whether their respiratory symptoms and radiographic appearances were related entirely to this or whether they had additional pulmonary disease. Taking the group as a whole the diagnosis of Macleod's syndrome had been considered at some time in 11 children. At the time of referral, four of these children had small hyperlucent lungs, six had lungs of normal size, and one (patient 12) had a large hyperlucent lung which had appeared of normal size previously.

All children had chest radiographs and fluoroscopy and underwent regional lung function studies. These were carried out using nitrogen-13. Both bolus inhalation and bolus injection studies were carried out. ${ }^{6}$ The distribution of gas and blood throughout both lung fields was determined. The clearance of gas from the lungs after bolus 
Table 1 Patients' ages, presenting symptoms, chest radiographic appearances, and initial diagnosis

\begin{tabular}{|c|c|c|c|c|}
\hline Patient & Age & $\begin{array}{l}\text { Presenting symptons/signs } \\
\text { and history }\end{array}$ & Chest radiographic appearance & Referring/initial diagnosis \\
\hline 1 & $2 \mathrm{yr}$ & $\begin{array}{l}\text { Chronic respiratory failure. } \\
\text { "Measles" age } 1 \text { yr. High } \\
\text { adenoviral titres }\end{array}$ & Small hyperlucent left lung & ?Macleod's syndrome \\
\hline 2 & $9 \mathrm{mo}$ & Wheezing since age $6 \mathrm{wk}$ & $\begin{array}{l}\text { Changes suggestive of right middle lobe and } \\
\text { lower lobe disease up to } 6 \text { mo. Age } 9 \text { mo, } \\
\text { hyperlucent small right lung }\end{array}$ & ?Macleod's syndrome \\
\hline 3 & $11 \mathrm{yr}$ & $\begin{array}{l}\text { Pertussis aged } 4 \mathrm{mo} \text { and } \\
\text { pneumonia. Haemoptysis age } 1 \mathrm{yr}\end{array}$ & $\begin{array}{l}\text { Recurrent collapse/consolidation left lower lobe } \\
\text { in early childhood. Hyperlucency left lower zone } \\
\text { age } 11 \text { yr. Lung of normal size }\end{array}$ & ?Macleod's syndrome \\
\hline 4 & $6 \mathrm{yr}$ & Recurrent chest infections & Hyperlucent left lung of normal size & ?Macleod's syndrome \\
\hline 5 & $6 \mathrm{yr}$ & Recurrent wheezing & $\begin{array}{l}\text { Normal until age } 3 \mathrm{yr} \text {; subsequently small } \\
\text { hyperlucent left lung }\end{array}$ & ?Macleod's syndrome \\
\hline 6 & $2 \mathrm{yr}$ & $\begin{array}{l}\text { Recurrent chest infections and } \\
\text { wheezing since age } 3 \text { mo }\end{array}$ & Hyperlucent left lung of rormal size & ?Macleod's syndrome \\
\hline 7 & $4 \mathrm{yr}$ & $\begin{array}{l}\text { Short of breath on exercise. } \\
\text { Known ventricular septal defect }\end{array}$ & $\begin{array}{l}\text { Hyperlucent left upper zone. Left lung of normal } \\
\text { size }\end{array}$ & ?Macleod's syndrome \\
\hline 8 & $7 \mathrm{yr}$ & $\begin{array}{l}\text { Murmur since birth. Valvar } \\
\text { pulmonary stenosis at cardiac } \\
\text { catheterisation. Asymptomatic }\end{array}$ & Small hyperlucent left lung on routine X-ray & ?Macleod's syndrome \\
\hline 9 & $3 \mathrm{mo}$ & $\begin{array}{l}\text { Patent ductus arteriosus ligated } \\
\text { age } 1 \text { mo. Persistent tachypnoea }\end{array}$ & Hyperlucent large left upper lobe & Congenital lobar emphysema \\
\hline 10 & 4 days & Respiratory distress from birth & Hyperlucent large left lung & Respiratory distress syndrome \\
\hline 11 & $4 \mathrm{mo}$ & $\begin{array}{l}\text { Respiratory distress and cardiac } \\
\text { murmur from birth }\end{array}$ & Hyperlucent right middle lobe & $\begin{array}{l}\text { ?Congenital lobar emphysema } \\
\text { ?Compensatory emphysema }\end{array}$ \\
\hline 12 & $6 \mathrm{mo}$ & Tachypnoea during infancy & $\begin{array}{l}\text { Hyperlucent large left lung which looked to be of } \\
\text { normal size on previous films }\end{array}$ & ?Macleod's syndrome \\
\hline 13 & $13 \mathrm{mo}$ & $\begin{array}{l}\text { Endocardial fibroelastosis. } \\
\text { Tachypnoea for six mo }\end{array}$ & Hyperlucent left lung of normal size & ?Macleod's syndrome \\
\hline 14 & $12 \mathrm{yr}$ & $\begin{array}{l}\text { Mustard repair of transposition } \\
\text { great vessels age } 4 \text { yr. Recurrent } \\
\text { wheezing since }\end{array}$ & $\begin{array}{l}\text { Hyperlucent left upper zone. Left lung of normal } \\
\text { size }\end{array}$ & Asthma \\
\hline 15 & $5 \mathrm{mo}$ & $\begin{array}{l}\text { Ventricular septal defect. Referred } \\
\text { age } 2 \text { mo. Persistent tachypnoea } \\
\text { and wheeze }\end{array}$ & $\begin{array}{l}\text { Hyperlucent left lung. Size normal large or small } \\
\text { on different X-rays }\end{array}$ & $\begin{array}{l}\text { ?Congenital lobar emphysema } \\
\text { ?Compensatory emphysema }\end{array}$ \\
\hline 16 & $2 \cdot 5 \mathrm{yr}$ & $\begin{array}{l}\text { Recurrent chest infection and } \\
\text { wheeze }\end{array}$ & Hyperlucent left lung of normal size & ?Macleod's syndrome \\
\hline 17 & $1 \mathrm{yr}$ & $\begin{array}{l}\text { Cardiac murmur. Known } \\
\text { unilateral pulmonary artery. } \\
\text { Poor exercise tolerance }\end{array}$ & Small hyperlucent right lung & $\begin{array}{l}\text { Unilateral pulmonary artery. } \\
\text { ? Ventilatory function of right lung } \\
\text { before surgery }\end{array}$ \\
\hline
\end{tabular}

inhalation represented fractional ventilation and was determined for each of four areas, right and left upper and lower zones. The clearance of gas from the lungs after the injection study reflected ventilation of perfused areas. Thus any delay in clearance of ${ }^{13} \mathrm{~N}$ suggested gas trapping and any difference in the rates of clearance after inhalation and injection studies represented ventilationperfusion imbalance. Depending on the results of the regional studies further investigations were carried out as detailed in table 2 .

Ten children in whom a definite diagnosis remained uncertain after the regional studies were referred for bronchoscopy or bronchography or both. Bronchography was performed under general anaesthetic, and where previous investigations had indicated the possibility of an abnormality of one of the principal bronchi, the bronchogram was preceded by bronchoscopy which was performed in the radiology department during the same. anaesthetic. After bronchoscopy an endotrachea $\mathbb{N}$ tube was inserted and a pre-curved nylon cannulan (OD $2.1 \mathrm{~mm}$; Portex Ltd) passed through the tuben into the lungs. A suspension of propyliodone $\mathbf{B P}_{\sigma}^{\omega}$ was used for bronchography (Dionosil Oily, Glaxo₹ Laboratories Ltd) which was performed under? fluoroscopic control with appropriate films exposedes from an under-couch tube (focal spot $0.6 \mathrm{~mm}$ ). Where the respiratory reserve was adequate bi-o lateral bronchograms were obtained, the lungsi being catheterised selectively in turn. Where $a b-\bar{D}$ normal variations in bronchial calibre were ob-음 served during fluoroscopy, they were recorded on $70 \mathrm{~mm}$ film exposed at three frames per second. 
Table 2 Investigations and final diagnoses

\begin{tabular}{|c|c|}
\hline Patient & Other investigations \\
\hline 1 & $\begin{array}{l}\text { Fluoroscopy-mediastinal movement to hyperlucent side on } \\
\text { inspiration. Bronchoscopy-no bronchial obstruction seen. } \\
\text { Open lung biopsy-chronic round cell infiltrate around } \\
\text { bronchioles }\end{array}$ \\
\hline 2 & $\begin{array}{l}\text { Bronchogram-narrowed RML and RLL bronchi with poor } \\
\text { peripheral filling. } \\
\text { RML and RLL lobectomies for repeated pneumonia-chronic } \\
\text { round cell infiltrate around bronchioles }\end{array}$ \\
\hline 3 & $\begin{array}{l}\text { Bronchoscopy-white tenacious sputum from LLL bronchus. } \\
\text { Bronchogram-saccular bronchiectasis lingula and LLL }\end{array}$ \\
\hline 4 & $\begin{array}{l}\text { Bronchoscopy-compression of posterior wall of } \mathbf{L} \text { main } \\
\text { bronchus with pulsation in time with cardiac cycle }\end{array}$ \\
\hline 5 & $\begin{array}{l}\text { Fluoroscopy - no mediastinal shift. } \\
\text { Bronchoscopy-granulations almost occluding } \mathbf{L} \text { main bronchus. } \\
\text { Histology of granulations-chronic inflammatory tissue }\end{array}$ \\
\hline 6 & $\begin{array}{l}\text { Cine-bronchogram-collapse of } \mathbf{L} \text { main bronchus during } \\
\text { expiration }\end{array}$ \\
\hline 7 & Arteriogram-branch stenosis of $\mathbf{L}$ pulmonary artery \\
\hline 8 & Further investigation not planned at present \\
\hline 9 & $\begin{array}{l}\text { LUL lobectomy. Emphysematous lung. Bronchi not } \\
\text { histologically examined }\end{array}$ \\
\hline 10 & LUL lobectomy. Accident in preparation of specimen \\
\hline 11 & $\begin{array}{l}\text { Bronchogram-RML bronchial narrowing. Collapse of } \mathbf{L} \text { main } \\
\text { bronchus during expiration. } \\
\text { RML lobectomy-reduction in cartilaginous plates throughout } \\
\text { bronchi }\end{array}$ \\
\hline 12 & $\begin{array}{l}\text { Bronchogram-narrow segment } L \text { main bronchus. } \\
\text { Barium swallow-L sided oesophageal compression }\end{array}$ \\
\hline 13 & $\begin{array}{l}\text { Cardiac catheterisation-fibroelastosis. All chambers grossly } \\
\text { dilated }\end{array}$ \\
\hline 14 & $\begin{array}{l}\text { Bronchogram-narrowed orifice of LLL bronchus. Other } \\
\text { bronchi normal }\end{array}$ \\
\hline 15 & Further investigation not necessary \\
\hline 16 & $\begin{array}{l}\text { Bronchogram-bilateral bronchiectasis. Crowding and } \\
\text { narrowing of LUL and LLL bronchi }\end{array}$ \\
\hline 17 & Further investigation not necessary \\
\hline
\end{tabular}

Final diagnosis

Macleod's syndrome with bilateral disease (on the basis of regional studies)

Macleod's syndrome

Bronchiectasis

Probable abnormal position of left main pulmonary artery (no further investigations permitted)

Occlusion of $\mathrm{L}$ main bronchus casuse by granulations? secondary to inhaled foreign body. Symptoms and chest X-ray improved after removal

Bronchomalacia

Branch pulmonary artery stenosis and ventricular septal defect.

Pulmonary stenosis (valvar)

Congenital lobar emphysema-LUL

Congenital lobar emphysema-LUL

Congenital lobar emphysema-RML with $L$ main bronchial narrowing.

Aortic stenosis

Tracheal cyst-surgically removed.

Patient cured

Endocardial fibroelastosis. ?Compression $\mathbf{L}$ main bronchus caused by large $L$ atrium (Incomplete investigation, postmortem not permitted)

Compensatory emphysema $2^{\circ}$ to partial left lower lobe collapse.

Congenital lobar empinysema $-L$ lung (managed conservatively)

Bilateral bronchiectasis

Absent $L$ main pulmonary artery. Function of $L$ lung normal

LUL = left upper lobe, $\mathrm{LLL}=$ left lower lobe, $\mathrm{RML}=$ right middle lobe, $\mathrm{RLL}=$ right lower lobe.

\section{Results}

Chest fluoroscopy to examine diaphragmatic and mediastinal respiratory movements was performed in all 17 children but in all but two (patients 1 and 5) no abnormality was demonstrated. Patient 1 , one of the two children given a final diagnosis of Macleod's syndrome, had characteristic movement of the mediastinum towards the hyperlucent side on inspiration.

Regional lung function studies showed that in all cases except one (case 14) the peak counts in both inhalation and infusion studies suggested that there was reduced gas and blood reaching the hyperlucent areas in comparison to the other areas. In case 14 the hyperlucent area received more gas and blood than the other areas. This child was subsequently shown to have partial left lower lobe collapse not evident on chest radiograph and thus had compensatory emphysema.

Three children (patients 7,8 , and 17) showed normal rates of clearance of gas from all regions of both lungs after inhalation and infusion, despite the reduction in peak counts in the hyperlucent areas. All had abnormal pulmonary vascular anatomy - unilateral peripheral pulmonary artery stenosis (patient 7), pulmonary valve stenosis (patient 8), and absent pulmonary artery (patient 17). Thus these children had hyperlucent lungs which were relatively underperfused but had normal ventilatory function. Bronchoscopy and bronchography were therefore not necessary as their 
symptoms and radiographic appearances could be related entirely to their congenital heart disease.

Nine patients $(2-6,9,10,12$, and 13) had delayed clearance of gas from the hyperlucent lung or area only. One child (patient 14) had normal clearance from his hyperlucent left upper zone but delayed clearance from the lower zone on the same side. All of these children except one who was too ill (patient 13) proceeded to bronchoscopy and/or bronchography, or surgery.

Four patients $(1,11,15$, and 16) showed delayed rates of clearance from both lungs suggesting generalised poor ventilatory function. Patient 1 was in severe respiratory failure and it was considered unwise to perform bronchography. An endoscopic lung biopsy showed histological changes consistent with post-viral bronchiolitis. Patient 11 was shown at bronchography to have narrowing of the left main bronchus on expiration as well as narrowing of the right middle lobe bronchus (figure). This child underwent right middle lobectomy and one year later is asymptomatic. Repeat regional studies now show normal clearance rates from both sides. Patient 15 had delayed clearance from the hyperlucent left lung as well as the collapsed right upper lobe although clearance from the rest of the right lung was normal. These results suggested that the hyperlucency of the left lung was not caused by compensatory emphysema but by emphysema secondary to airway obstruction. This child's symptoms have improved without surgical intervention. Patient 16 had bilateral bronchiectasis and was discharged abroad to be managed medically.

\section{Treatment and outcome}

Three patients (patients 9, 10, and 11) had lobectomies for congenital lobar emphysema and would have had this treatment whether or not regional studies and bronchography had been carried out. Nevertheless both surgeon and anaesthetist had the benefit of knowing the function of the other lung and lobes. In patients 9 and 10 this was normal but in patient 11 the opposite main bronchus was stenosed. Three other children, all referred as Macleod's syndrome, underwent surgery. One had a tracheal cyst (patient 12) and had been wheezing since birth. Another (patient 2) underwent right middle and right lower lobe lobectomies because of recurrent pneumonia. Both lobes showed changes consistent with post-viral bronchiolitis. The third (patient 5) had a granuloma removed from the left main bronchus. Before surgery this child's chest radiograph had shown that the left lung was small and hyperlucent. This appearance returned to normal after surgery All children who underwent surgery responded favourably.

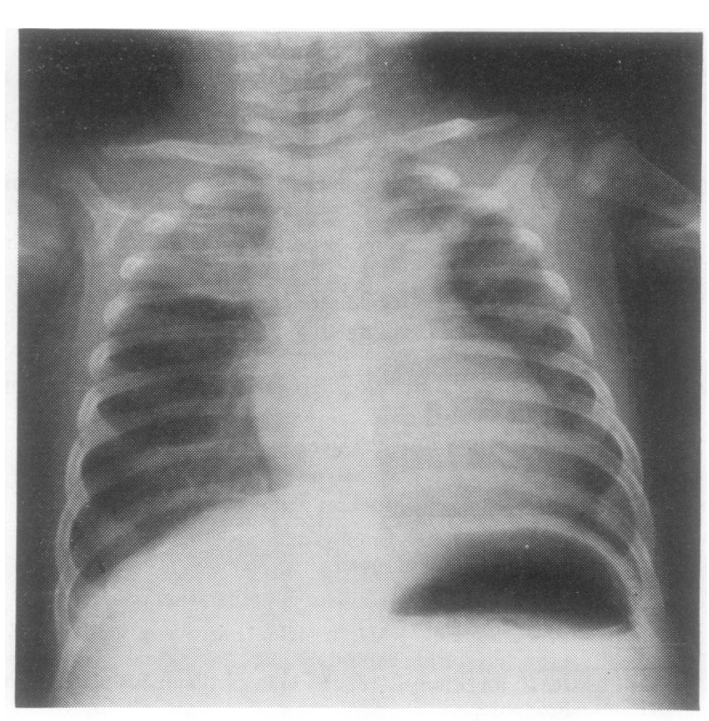

(a)

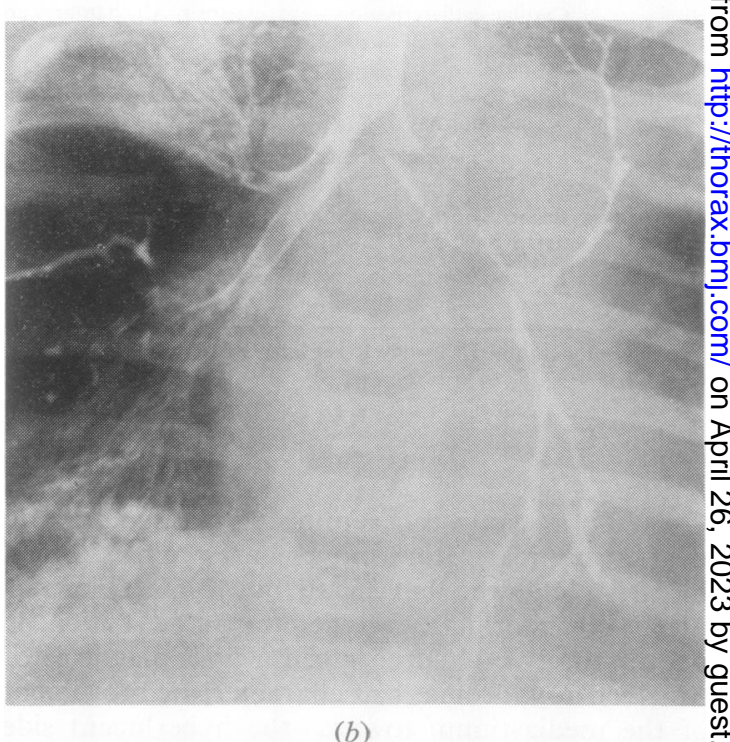

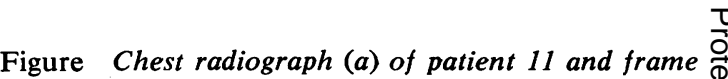
from cine-bronchogram (b) taken in expiration. The chest radiograph shows hyperlucency of the right mid $₫$ zone and the bronchogram shows almost complete occlusion of the left main bronchus on expiration in addition to stenosis of the right middle lobe bronchus. 
Two children had bronchiectasis. In patient 16 , regional function studies and bronchography suggested bilateral disease, not evident from the chest radiograph. The site of pathology is clearly important in planning physiotherapy. The child with partial left lower lobe collapse underwent physiotherapy and is now well.

Apart from the child with endocardial fibroelastosis who died, the remaining children were managed conservatively.

\section{Discussion}

This study emphasises the variety of causes of unilateral hyperlucent lungs. Of the 11 children referred with a diagnosis of possible Macleod's syndrome post-viral bronchiolitis was the final diagnosis in only two and regional studies suggested that one of these had bilateral disease. As some of these children had surgically treatable conditions and others had abnormal pulmonary vasculature only, we feel that the terms "Macleod's syndrome" and "Swyer-Jones syndrome" should be reserved only for children in whom other causes of respiratory symptoms have been ruled out. Investigation for many children meant not only a change in diagnosis but a significant change in treatment. Patients 5, 12, and 16 for example had been wheezing for some time before being referred.

Regional studies were useful initial investigations for three reasons. Firstly they distinguished children with unequal pulmonary perfusion in the absence of primary lung disease. Several forms of congenital heart disease other than branch pulmonary stenosis are associated with unequal lung vascularity. ${ }^{78}$ Although the distribution of ventilation favoured the well-perfused lung, the ventilatory turnover on both sides was normal. Previous studies with ${ }^{99 \mathrm{~m}}$ Technetium and ${ }^{133}$ Xenon $^{9}{ }^{10}$ have shown similar findings in children with unilateral pulmonary artery and recent studies in newborn animals have shown that when the pulmonary artery supply is interrupted to one lung, that lung fails to grow normally, remaining abnormally small. ${ }^{11}$ Thus the results of the ventilation scan in the three children with primary perfusion abnormalities suggest that the under-perfused regions were small in comparison to the other regions. Secondly, regional studies were useful in identifying children with bilateral disease. Congenital lobar emphysema usually affects only one lobe of one lung ${ }^{12}$ but occasionally the presence of bilateral disease may not be appreciated, as in patient 11 in this series. Abnormal variations in bronchial calibre were seen on fluoroscopy at bronchography possibly due to soft bronchial cartilage. Repeat studies were of interest in the follow-up of this child and demonstrated, as others have, ${ }^{13}$ that infantile lobar hyperinflation does improve over the first year of life in some children. Thirdly, the interpretation of chest radiographs showing areas of hyperlucency together with areas of collapse may be difficult, particularly if the radiographic signs change from day to day as in patient 15 . These signs may be the result either of lobar collapse with compensatory emphysema or collapse secondary to congenital lobar emphysema. In compensatory emphysema gas and blood are both distributed principally to areas of hyperlucency and clearances are normal, as in patient 14. In congenital lobar emphysema, however, the hyperlucent areas are poorly ventilated and perfused as in patients 9 and 10 .

Fluoroscopy may be helpful if definite mediastinal shift is seen. Characteristically on expiration the mediastinum moves away from the hyperlucent side in Macleod's syndrome and when there is bronchial narrowing and air trapping. However, in our experience fluoroscopy was not very useful because we rarely saw definite shift. Fluoroscopy in patient 5 , for example, was inconclusive. Bronchoscopy and bronchography are not easy procedures in children, particularly in those with poor respiratory reserve. Thus regional studies may not only help in distinguishing those children in whom these procedures are unnecessary but also help in localising the areas of good and poor function, of interest to anaesthetist, radiologist, and surgeon.

Nitrogen-13 was used in this study because it was available to us and because we were interested in evaluating its usefulness. Technetium-99m and Krypton- $81 \mathrm{~m}$ for perfusion and ventilation studies respectively are more readily available. As it is now possible to measure the rate of clearance of ${ }^{81 \mathrm{~m}} \mathrm{Kr}$ from the lungs, information about the distribution of pulmonary blood flow and ventilation in children with lungs of unequal size should be more easily obtainable using a combination of these isotopes.

This study has shown that a significant proportion of children referred to us with hyperlucent lungs had treatable disorders and therefore merited careful investigation. To avoid confusion we suggest that Macleod's syndrome is reserved exclusively for children with post-viral bronchiolitis and should not be used as a blanket diagnosis for unilateral hyperlucent lungs for which there is no obvious aetiology. If regional studies are available to the clinician they may be helpful in indicating children who do not need further in- 
vasive investigation and in defining the extent of altered respiratory function.

We are grateful to the staff of the MRC cyclotron unit who provided the isotope, to Dr M Fitzpatrick and Miss $M$ Tooley for helping with the regional lung function studies, and to our colleagues who referred many of the patients.

\section{References}

1 Macleod WM. Abnormal transradiancy of one lung. Thorax 1954; 9:147-53.

2 Swyer PR, James GCW. A case of unilateral pulmonary emphysema. Thorax 1953; 8:133-6.

3 Reid L, Simon G, Zorab, RA, Seidelin R. The development of unilateral hypertransradiancy of the lung. Br J Dis Chest 1967; 61:190-2.

4 Cumming GR, MacPherson RI, Chernick V. Unilateral hyperlucent lung syndrome in children. $J$ Pediatr 1971; 78:250-60.

5 Stokes D, Sigler A, Khouri NF, Talamo RC. Unilateral hyperlucent lung (Swyer-Jones syndrome) after severe Mycoplasma pneumoniae infection Am Rev Respir Dis 1978; 117:145-52.

6 Ronchetti R, Stocks J, Freedman N, Glass $H_{0}^{\Phi}$ Godfrey $S$. The clinical application of regionad lung function studies in infants and small childrern using ${ }^{13}$ N. Arch Dis Child 1975; 50:595-603.

7 Whitley JE, Rudhe U, Herzenberg H. Decreased left lung vascularity-congenital left to righw shunts. Acta Radiolo (Diagn) 1963; 1 NS:1125-31

8 Wilson WJ, Amplatz K. Unequal vascularity ink tetralogy of Fallot. AJR 1967; 100:318-21.

9 Moser KM, Guisan M, Cuomo A, Ashburn WL Differentiation of pulmonary vascular from? parenchymal diseases by ventilation/perfusions scintiphotography. Ann Intern Med 1971; 75: 597-605.

10 Treves S, Ahnberg DS, Laguarda R, Strieder DJ.Radionuclide evaluation of regional lung function in children. J Nucl Med 1974; 15:582-7.

11 Haworth SG. Personal communication, 1980.

12 Lincoln JCR, Start J, Subramanian S et al. Congenital lobar emphysema. Ann Surg 1970; 173:0 55-62.

13 Shannon DC, Todres ID, Moylan FMB. Infantiled lobar hyperinflation: expectant treatment. Pedi-O atrics 1977; 59:1012-8. 